\title{
Impact of Thickness on the Optical Properties of Selenium Thin Films
}

Impacto del espesor sobre las propiedades ópticas de las películas finas de

selenio

Submitted on: May 5, 2019| Accepted on: June 6, 2020 | Published on: June 17, 2021

\author{
Shiva Udachan ${ }^{\text {a }}$ \\ Rani Channamma University, India \\ ORCID: 0000-0002-0810-8353 \\ Narasimha Ayachit \\ Rani Channamma University, India \\ ORCID: 0000-0002-5463-2586 \\ Lingappa Udachan \\ Channabasaveshwar Arts, Science and Commerce College, India \\ ORCID: 0000-0001-9028-9837 \\ Raghunanda Halembre \\ Government First Grade College, India \\ ORCID: 0000-0003-1661-6566 \\ a Corresponding author. E-mail: shivaudachan8@gmail.com
}

DOI: https://doi.org/10.11144/Javeriana.iued25.itop

How to cite this article:

S. Udachan, N. Ayachit, L. Udachan, and R. Halembre, "Impact of thickness on the optical properties of selenium thin films," Ing. Univ., vol. 25, 2021 [Online]. https://doi.org/10.11144/Javeriana.ived25.itop 


\section{Abstract}

Objectives: The primary objective of this investigation is to make a systematic study on the impact of thickness on optical properties, such as energy gap, absorption coefficient, optical density etc., for selenium thin films. Understanding of the band gap energy and its influence on film thickness is of utmost importance in acquiring the intended electrical characterization of semiconducting films. Materials and methods: Ultra-purity selenium (99.99\%) was deposited on glass substrates. During deposition, the glass substrate with its holder were rotated with constant speed to have a smooth coating. Results and discussions: The XRD findings indicate that selenium is amorphous in nature. The optical band gap energy is found to be decreasing form (2.3 to $2 \mathrm{eV})$ with the rise of film thickness in interval (200 to $1000 \mathrm{~nm}$ ). The band gap energy obeys inverse square law with respect to thickness. Conclusion: We have properly grown thin films of Se below the De Broglie wavelength limit by thermal evaporation in vacuum. The optical density varies directly with film thickness. The absorption coefficients were in the interval $(0.5$ to 4$) \times 107 \mathrm{~m}^{-1}$. The AFM results confirmed that the Se nano-size increases with the increase in thickness. Both the grain boundaries and sub-grain regions are clearly visible in the SEM micrographs

Keywords: Absorption coefficient, band gap, optical properties of Se thin films

\section{Resumen}

Objetivos: El objetivo principal de esta investigación es el de realizar un estudio sistemático sobre el impacto que tiene el espesor sobre las propiedades ópticas tales como la banda prohibida, coeficiente de absorción, densidad óptica, entre otras, para las películas finas de selenio. La comprensión de la banda prohibida y su influencia en el espesor de la película es de suma importancia para la adquisición de la caracterización eléctrica deseada de las películas semiconductoras. Materiales y métodos: Se depositó selenio de ultra pureza $(99,99 \%)$ sobre sustratos de vidrio. Durante la deposición, se hizo girar el sustrato de vidrio en su respectivo soporte a velocidad constante para obtener un recubrimiento uniforme. Resultados y discusión: Los hallazgos de XRD indican que el selenio es de naturaleza amorfa. Se encuentra que la banda prohibida de la banda óptica toma forma descendente $(2,3 \mathrm{a} 2 \mathrm{eV})$ con el aumento del espesor de la película en el intervalo 200 a $1000 \mathrm{~nm}$. La banda prohibida de la banda obedece la ley del cuadrado inverso respecto al espesor. Conclusión: Hemos generado correctamente películas finas de Se por debajo del límite de longitud de onda de De Broglie mediante evaporación térmica en vacío. La densidad óptica varía directamente con el espesor de la película. Los coeficientes de absorción se ubicaron en el intervalo $(0,5$ a 4$) \times 107 \mathrm{~m}^{-1}$. Los resultados de AFM confirmaron que el tamaño nanométrico de Se aumenta con el incremento del espesor. Tanto los límites del grano como las regiones subgranulares son claramente visibles en las micrografías SEM.

Palabras clave: coeficiente de absorción, banda prohibida, propiedades ópticas de películas finas de $\mathrm{Se}$ 


\section{Introduction}

Thin-film technology is used in many applications such as microelectronics, optics, magnetic-, hard-, and corrosion-resistant coatings, and micro-mechanics [1]. Advances of thin film growth technology over the past two decades has led to oxide heterostructures synthesis by a variety of techniques, including sputter techniques and molecular beam epitaxial for use in electro-optical devices, space science, solar cell energy utilization etc., [1]-[4]. Engineers made a promising material stable enough for use in solar cells: simply changing to a perovskite surface removes barriers to its functionality [5], [6].

Optical measurements on thin films provide a good technique for assessing the properties of semiconductors. Particularly, the measurement of absorption coefficient for various energies gives a lot of information about the band gaps of the material. Knowledge of the band gap and its dependence on the film thickness is extremely important in achieving the required electrical properties of a semiconductor for specific applications. In particular, the measurement of absorption coefficients for various incident energies of photons on Se films throws light on the band gap of materials. Knowledge of optical constants of a material such as optical band gap, refractive index and extinction coefficient is quite essential to examine material's potential opto-electronic applications [5]. Understanding and knowledge of these band gaps is of primary importance for awareness of the electrical resistivity and carrier mobility of semiconductors [6]. In addition, it is widely used in the production of photocells, exposure meters for photographic use, and in reprography [5] for reproducing and copying documents.

Electrical and optical properties are very much influenced by various deposition parameters such as film thickness [7], rate of evaporation [8], substrate temperature [9], crystalline structure [10], base pressure [11], substrate material [12], and the ambient gas [13] present in the vacuum chamber.

Apart from this, selenium is used as a material in electro-photography [14], x-ray photoconductors [15], high-definition digital video cameras [16], pigments [17], semiconductors [18], filament detector arrays [19], medical imaging sensors [20], to improve the thermal stability of photosensors [21], optical applications in the IR region [22], photonic devices [23], and superconductors [24].

In view of the above, interesting properties and little work have been reported on the optical properties of thin selenium films [25], [26] and these background facts prompted us to undertake this study. Hence, we have chosen Se as it is, a nonmetal, in order to study its optical properties in thin film form. 


\section{Theoretical Section}

Analysis of optical absorption spectra is one of the most productive tools for understanding and developing the band structure and energy gap. The optical absorption coefficient $(\alpha)$ is related to the transmission ( $T$ ) of a specimen [27] is given by equation (1).

$$
\alpha=\ln (1 / \mathrm{T}) / \mathrm{t}
$$

Where,

$t=$ thickness of the films.

Since Se, a non-metal, is a direct band gap material and for direct allowed transitions, the absorption coefficient $(\alpha)$ is related to band gap energy by the relation [28] and is shown in equation (2).

$$
(\alpha h v)=B(h v-E g) 1 / 2
$$

Where,

$h v$ is the energy of the incident photon,

$E_{g}$ is the optical band gap energy of the material, and $B$ is a constant, which has different values for different transitions.

The energy gap is evaluated for different thicknesses $(\mathrm{t})$ and the band gap variation with the film thickness follows the relation [29] is mentioned in the equation (3).

$$
\Delta \mathrm{E}=\frac{(\hbar \pi)^{2}}{2 \mathrm{~m}^{*} \mathrm{t}^{2}}
$$

Where,

$m *$ is the effective mass of the charge carriers,

(t) is the thickness,

(h) is the Planck's constant,

and $\Delta \mathrm{E}$ is the kinetic energy contribution due to motion normal to the film plane.

In the present investigation, $\mathrm{Se}$ is a semiconducting material and it becomes necessary to estimate the De Broglie wavelength in order to select the thickness range of the film, where the investigation is to be carried out. The De Broglie wavelength $\left(\lambda^{\prime}\right)$ can be estimated using equation (4).

$$
\mathrm{Ef}=\frac{\mathrm{hc}}{\lambda^{\prime}}
$$

Where,

$\mathrm{h}=$ Planck's constant,

$\mathrm{c}=$ Speed of light,

$\mathrm{E}_{\mathrm{f}}=$ Fermi energy $=1.0643 \mathrm{eV}=$ half of the average band gap energy. 


\section{Experimental Section}

Selenium of $99.99 \%$ purity (obtained from Leico Industries, New York, USA) was thermally evaporated by resistive heating at room temperature $\left(22^{\circ} \mathrm{C}\right)$ under a pressure of $\left(2 \times 10^{-6}\right)$ Torr using Hind High Vacuum coating unit model 12A4D. The rate of deposition was around (1-2) nms $\mathrm{s}^{-1}$.

The distance between the substrate and the evaporation source was approximately $20 \mathrm{~cm}$. Before deposition, the substrates were treated with various cleaning techniques including ultrasonically agitation method. Lastly, the substrate was cleaned through the ionic bombardment method in the vacuum chamber before deposition. During deposition, the substrate holder was rotated with a constant speed as to have a smooth surface of the sample as required in optical studies.

The film thickness and deposition rate were controlled by means of an built-in quartz crystal digital thickness monitor (Model DTM-101), which could resolve thickness up to $0.1 \%$ in the vacuum coating unit system. The transmittance spectra $(\mathrm{T} \%)$ were taken at room temperature by using a spectrophotometer in the wavelength $(\lambda)$ spectral range of 200 to $800 \mathrm{~nm}$.

Nowadays, there are several thin film coating methods available [29]-[32]. Among them, thermal evaporation in vacuum happens to be the best method because it gives films with no impurities as required in many scientific investigations. Glass slides were used as substrates in the present investigation because of their di-electric nature.

\section{Results and Discussions Section}

Many experiments have been conducted to study the optical properties of Se thin films. Figure 1 shows a typical XRD pattern for one of the deposited Se thin film of thickness 210 $\mathrm{nm}$. The intensity data were collected over a range of $2 \theta$ is $15^{\circ}$ to $85^{\circ}$. The pattern shows that the film was amorphous in structure with peaks that started to grow and appear, which exhibit a prominent reflection angle $2 \theta=23.5^{\circ}$ and $2 \theta=29.5^{\circ}$.

There were similar results obtained in other studies [33], [34] which are in a good agreement with the results obtained by Roy et al. for selenium films [15].

The $\mathrm{x}$-ray diffraction studies of selenium film grown at room temperature reveal that they are fine grained and polycrystalline. X-ray diffraction data of selenium films well agrees with that of trigonal selenium peaks [JCPDS: 0362] [15], [17]. The XRD result showed that 
the selenium film is amorphous in nature due to this arrangement of atoms in thin films [35].

Figure 1. Plot of Intensity (cps) versus 20, The XRD pattern of Se thin films of thickness $210 \mathbf{n m}$

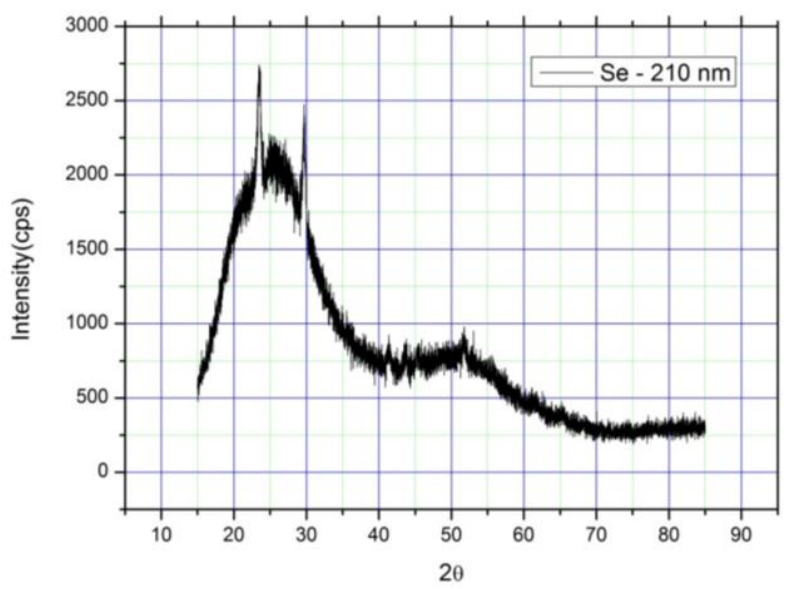

Source: Own source.

Visually, selenium films are found to be blackish grey in color with good adhesion to the substrate material. Figure 2 shows the plot of percentage transmittance (T\%) against the wavelength $(\lambda)$ of the incident radiation, in the range $200-800 \mathrm{~nm}$, at different Se films of thicknesses $(\mathrm{t})$ in the range $200-1000 \mathrm{~nm}$.

Figure 2. Plot of Transmittance (T \%) versus wave-length $(\lambda)$ of incident photon at different Se films thicknesses $(t)^{*}$

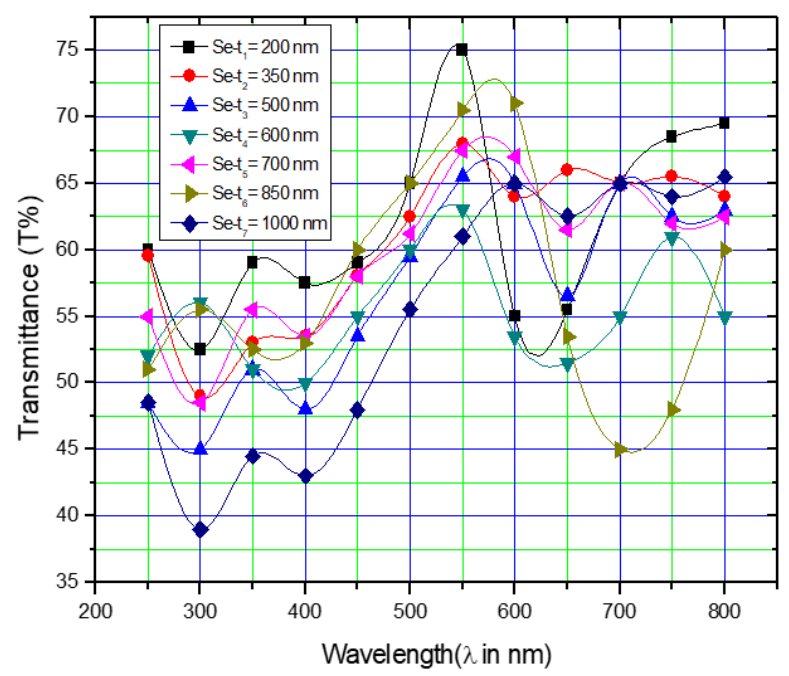

Source: Own source.

* Series 1, t1 $=200 \mathrm{~nm}$; Series 2, t2 = $350 \mathrm{~nm}$; Series 3, t3 = $500 \mathrm{~nm}$; Series 4, t4 = $600 \mathrm{~nm}$; Series 5, t5 = 700 $\mathrm{nm}$; Series 6, t6 = 850; and Series 7, $\mathrm{t} 7=1000 \mathrm{~nm}$ (table 2) 
It is observed that transmittance increases with a decrease in film thickness. According to figure 2, the optical transmission spectrum [T \%] of Se thin films, the spectrum shows the interference pattern. As it can be seen from this figure, the results obtained for Se films are characterized with transmission greater than $55 \%$ for wavelength values greater than 500 nm. Similar results were obtained by Harpreet Singh [23] for Se films, Jassim, Zumaila, and Waly [27] for CdS thin films and Anandh et al. [35] for CdSe films. It is observed that all the films are highly transparent, and the maximum transmittance is about $75 \%$.

Figure 3 shows the plot of optical absorption coefficient $(\alpha)$ against photon energy $(\mathrm{h} v)$ at different films thicknesses $(\mathrm{t})$. Series $1, \mathrm{t}_{1}=200 \mathrm{~nm}$; Series $2, \mathrm{t}_{2}=350 \mathrm{~nm}$; Series $3, \mathrm{t}_{3}=$ $500 \mathrm{~nm}$; Series 4, $\mathrm{t}_{4}=600 \mathrm{~nm}$; Series 5, $\mathrm{t}_{5}=700 \mathrm{~nm}$; Series 6, $\mathrm{t}_{6}=850 ;$ and Series7, $\mathrm{t}_{7}=$ $1000 \mathrm{~nm}$.

Figure 3. Plot of Absorption co-efficient $(\alpha)$ versus photon energy, hv in eV at different Se films thicknesses $(t)^{*}$

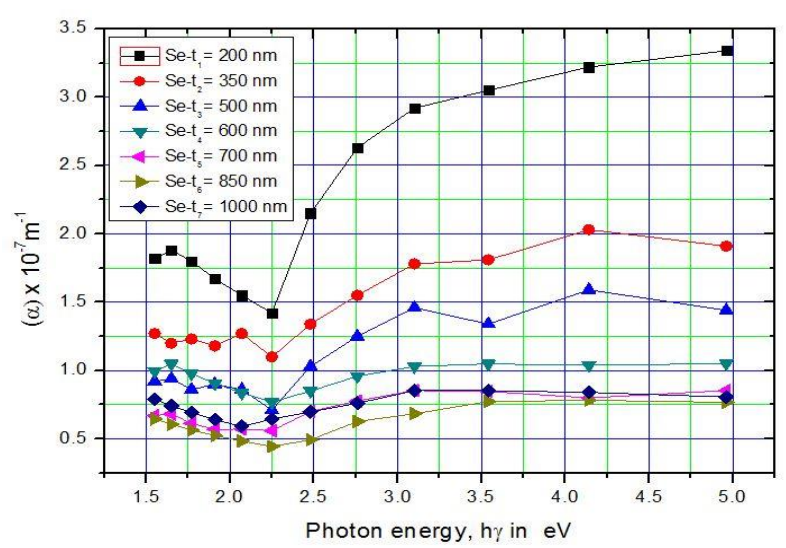

Source: Own source.

* See table 3.

Since absorption is a function of incident photon energy [26], based on figure 3, it appears

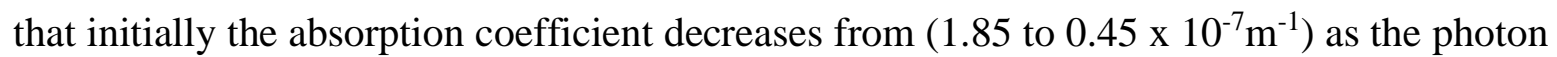
energy increases from ( 0.5 to $2.25 \mathrm{eV})$. Moreover, the absorption coefficient is high at the low region of incident photon energy while it becomes $\left(0.45 \times 10^{-7} \mathrm{~m}^{-1}\right)$ at high photon energy of $(2.25 \mathrm{eV})$. Further, the absorption increases from $\left[(0.75\right.$ to 3.3$\left.) \times 10^{-7} \mathrm{~m}^{-1}\right]$ with the increase in the photon energy from (2.25 to $5 \mathrm{eV})$. Similar behavior between absorptions and incident photon energy has been reported for selenium thin films by Mutar and Hemed [34]. In the case of tin oxide thin films, a similar trend in the curve has been noticed [36]. 
Figure 4 shows the typical plot of $(\alpha h v)^{2}$ against $(h v)$ for Se thin films. The optical band gap is calculated from the intercept $(h v=0)$ of the straight line. For allowed direct transitions, by extrapolating the straight-line portion of the plots towards low energy, the optical band gap energy can be obtained as shown in figure 4.

\section{Figure 4. Plot of $(\alpha h v)^{2}$ versus photon energy, $h v$ in $\mathrm{eV}$ at different Se films thicknesses ( $t$ )}

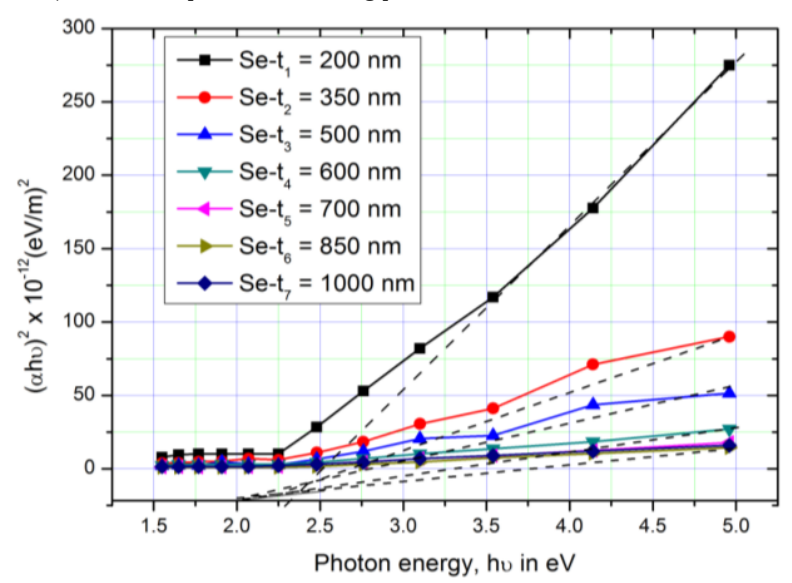

Source: Own source.

* Series $1, \mathrm{t}_{1}=200 \mathrm{~nm} ;$ Series 2, $\mathrm{t}_{2}=350 \mathrm{~nm} ;$ Series 3, $\mathrm{t}_{3}=500 \mathrm{~nm} ;$ Series 4, $\mathrm{t}_{4}=600 \mathrm{~nm} ;$ Series $5, \mathrm{t}_{5}=700$ $\mathrm{nm}$; Series 6, $\mathrm{t}_{6}=850$; and Series 7, $\mathrm{t}_{7}=1000 \mathrm{~nm}$ (table 4).

The extrapolation of plots of $(\alpha h v)^{2}$ versus (hv) onto energy axis will give the energy band gap. The energy band gap of films varied in the range (2.0 to 2.3) eV [37]. The value of the optical band gap energy is found to be decreasing from (2.3 to $2.0 \mathrm{eV})$ [35] as the film thickness increases from (200 to $1000 \mathrm{~nm}$ ), which shows its capabilities to be used as an absorber layer in photovoltaic applications and wide band gap materials (Cdo), suitable for solar cells [38].

In general, density of localized state in the film increases with the thickness, resulting in the decrease of band gap. Such a variation in energy band gap with the increase in thickness in $\mathrm{ZnO}$ [39], Sn Se [40], Bi $2 \mathrm{Te}_{3-\mathrm{x}} \mathrm{Se}_{\mathrm{x}}$ [41], $\mathrm{Sb}_{2} \mathrm{~S}_{3}$ [42], ZnS PbS Zn $\mathrm{Zn}_{1-\mathrm{x}} \mathrm{Pb}_{\mathrm{x}} \mathrm{S}, \mathrm{Zn}_{\mathrm{x}} \mathrm{Pb}_{1-\mathrm{x}} \mathrm{S}, \mathrm{Pb}$ $\mathrm{Zn}_{\mathrm{x}} \mathrm{S}_{1-\mathrm{x}}$ [43], and $\mathrm{LiNbO}_{3}$ [44] thin films has been reported. Moreover, the band gap energy for Se estimated by [25], [33] is consistent with the value obtained in this investigation.

From the results obtained in our experiment, the band gap mainly depends on the thickness of the film and the shift in the bandgap energy is attributed to the nanocrystalline quantum size effect [44].

The values of the optical band gap energy $\left(\mathrm{E}_{\mathrm{g}}\right)$ investigated for Se are given in table 1 . 
Table 1. Optical band gap and thickness of Se films

\begin{tabular}{ccc}
\hline (t) in $\mathbf{~ n m}$ & $\left(\mathbf{1} / \mathbf{t}^{\mathbf{2}}\right) \mathbf{x} \mathbf{1 0}^{\mathbf{1 2}} \mathbf{m}^{-\mathbf{2}}$ & $\mathbf{E}_{\mathbf{g}}(\mathbf{e V})$ \\
\hline 200 & 25 & 2.30 \\
\hline 350 & 8.16 & 2.24 \\
\hline 500 & 4 & 2.18 \\
\hline 600 & 2.77 & 2.12 \\
\hline 700 & 2.04 & 2.06 \\
\hline 850 & 1.38 & 2.00 \\
\hline 1000 & 1 & 2.00 \\
\hline
\end{tabular}

Source: Own source.

The plot of $\left(E_{g}\right)$ versus $\left(1 / t^{2}\right)$ for Se films is given in figure 5, which is in good agreement with the above relation.

Semi-conductors and semi-metal films are expected to exhibit the quantum size effect [45] when the thickness of the films is found to be comparable with or less than the mean free path or less than the effective De Broglie wavelength of the carriers. Under such circumstances, the quantization of the transverse component of the quasi-momentum occurs because of finite size and thickness of the films. This allows the transverse components of the electron-states to occupy quasi-discrete energy values. Because of this quantization effect, an additional gap in the energy will be generated between the top of the valence band and the bottom of conduction band, by an amount $\Delta \mathrm{E}$, which is given by equation (3). Hence, the increase in the band gap energy in the present reference may be due to an additional contribution of energy to the energy band because of quantization effect.

Figure 5. Plot of band gap energy $\left(E_{g}\right)$ versus $\left(1 / t^{2}\right)$ for Se thin films of various thicknesses $(t)^{*}$

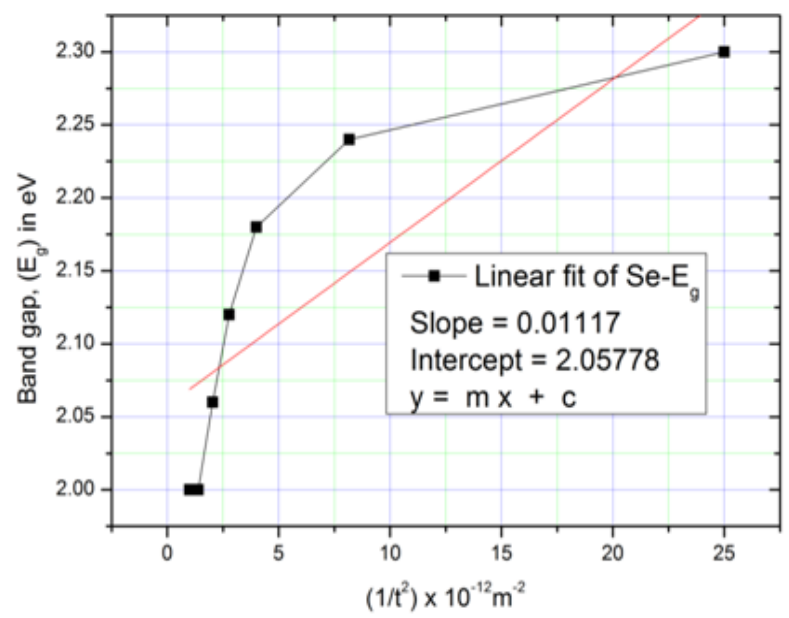

Source: Authors own elaboration

* See table 5 . 
From the slope of the curve of figure 5, we get the value for effective mass $m^{*}$ and found it to be $\left(0.3375 \times 10^{-4}\right)$ times $\mathrm{m}_{\mathrm{o}}$, where $\mathrm{m}_{\mathrm{o}}$ is the rest mass of carriers (electrons), i.e., $9.1 \mathrm{x}$ $10^{-31} \mathrm{Kg}$, which is comparable to that obtained for $\operatorname{In}_{0.1} \mathrm{Bi}_{1} \mathrm{Te}_{3}$ thin films [46].

The optical absorption coefficient $(\alpha)$ has high values for higher thickness films compared to that of lower thickness films. On the other hand, the optical density (OD) or the absorption is proportional to the thickness of the films [47] and is given by $(\alpha \times t)$. The variation of OD with the incident photon energy, $\mathrm{h} v$ in $\mathrm{eV}$ is depicted in figure 6.

\section{Figure 6. Plot of optical density (OD) $\times 10^{-14}$ versus the photon energy of Se at various films thicknesses}

$(t)$

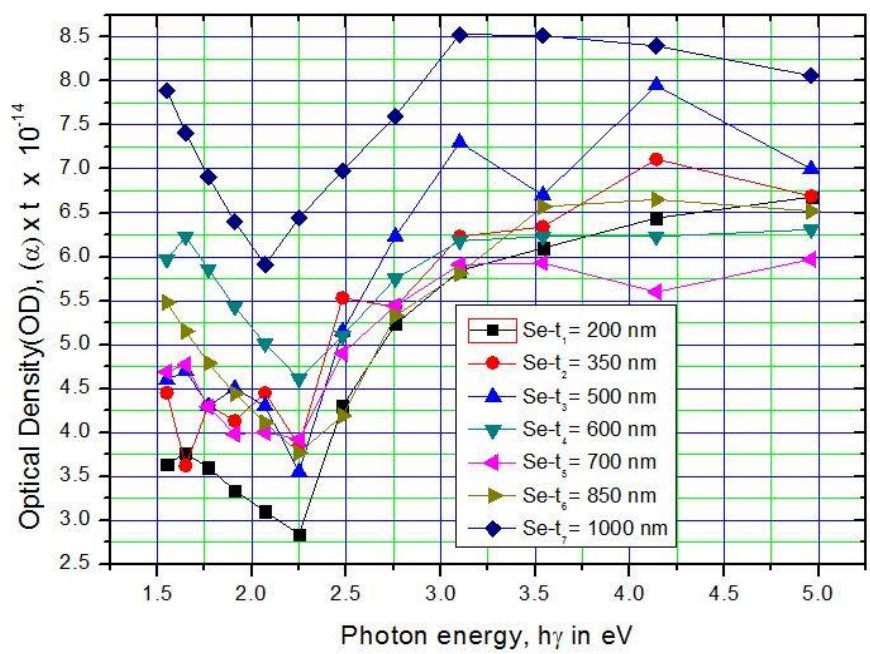

Source: Own source.

* Series $1, \mathrm{t}_{1}=200 \mathrm{~nm}$; Series 2, $\mathrm{t}_{2}=350 \mathrm{~nm}$; Series 3, $\mathrm{t}_{3}=500 \mathrm{~nm}$; Series 4, $\mathrm{t}_{4}=600 \mathrm{~nm}$; Series $5, \mathrm{t}_{5}=700$ $\mathrm{nm}$; Series 6, $\mathrm{t}_{6}=850$; and Series $7, \mathrm{t}_{7}=1000 \mathrm{~nm}$ (table 6)

Optical Intensity (OD) measures the amount of attenuation, or intensity lost, when light passes through an optical component. It also tracks attenuation based on the scattering of light, whereas the absorbance considers only the absorbance of light within the optical component. We obtained a minimum OD at the photon energy of $2.25 \mathrm{eV}$ for all selenium films, as it mainly depends on the incident photon energy. Initially as the incident photon energy increases from (1.5-2.25) eV, the OD decreases for all the thicknesses. Afterwards, the OD increases as the film thickness increases and with that, an increase in the photon energy from (2.5-5) eV. The maximum value of OD achieved in the present investigation is around $8.5 \times 10^{-14}$ as seen in figure 6. Our results are comparable with those reported for non-crystalline $\mathrm{Cd}_{50} \mathrm{~S}_{50-\mathrm{XSe}}$ thin films [47]. 
It is a customary to estimate electron conduction mean free path or De Broglie wavelength $\left(\lambda^{\prime}\right)$, while making a study on electrical/optical properties with metals or non-metallic films, respectively.

The De Broglie wavelength of electrons or holes, estimated by Fermi-energy taken to be half of the average band gap energy $(1.0643 \mathrm{eV})$, turns out to be about $1167 \mathrm{~nm}$. Hence, we need to select the thickness range around $1167 \mathrm{~nm}$ or less than that. Thus, the quantum size effect is expected to be shown by the films in the thickness range of 200-1000 nm [29], [41], [44], [45]. Such an increase in the band gap which is inversely proportional to the square of the film thickness, is attributed to the quantum effect.

In this study, a decrease in band gap energy with increase in film thickness is noticed which has been depicted in the figure 7. A similar trend has also been observed in CdS thin films [9].

Figure 7. Plot of energy gap $\left(E_{g}\right)$ versus thickness $(t)$ for Se thin films of various thicknesses

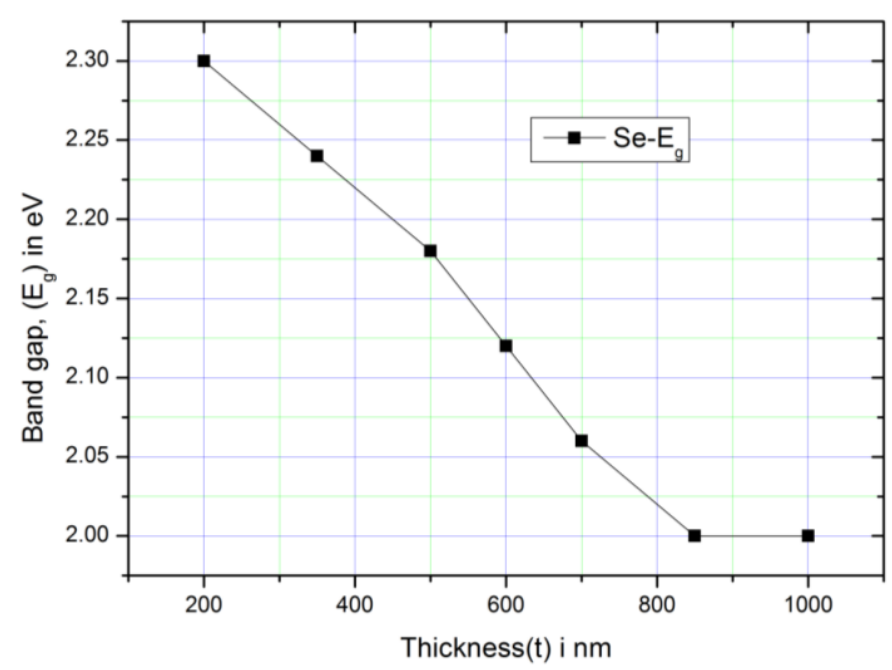

Source: Own source.

* Series 1, $\mathrm{t}_{1}=200 \mathrm{~nm}$; Series 2, $\mathrm{t}_{2}=350 \mathrm{~nm}$; Series 3, $\mathrm{t}_{3}=500 \mathrm{~nm}$; Series 4, $\mathrm{t}_{4}=600 \mathrm{~nm}$; Series $5, \mathrm{t}_{5}=700$ $\mathrm{nm}$; Series $6, \mathrm{t}_{6}=850$; and Series $7, \mathrm{t}_{7}=1000 \mathrm{~nm}($ table 7$)$

The band gap in the case of CdS thin films decreases with film thickness. In this study, the optical band gap decreases with the increase in the thickness of the film.

This variation is due to quantum size effect occurring in semi-conducting thin films. This is verified by figure 7 , in which optical band gap shows as a straight line up to the $850 \mathrm{~nm}$ thickness, which is comparable with mean free path and effective De Broglie wavelength of the carrier and then shows the constant value of band gap. Furthermore, the optical band gap decreases with thickness, which is explained in terms of quantum size effect [46]. 
The morphology of Se films of thicknesses 157 and $210 \mathrm{~nm}$ were observed by SEM and the images are presented in figure $8(a-b)$. The SEM micrographs obtained on the Se thin films are shown for the same magnification, 10,000 for different thicknesses. The marker represents $10 \mu \mathrm{m}$ in all the 2-micrographs. Similar types of grains were observed in the case of tin films as seen through TEM [48].

The scanning electron micrographs are helpful in elucidating the incipient growth of Se film on glass substrate. Figure 8 (a) shows SEM images of grains and sub-grains oriented in random directions with non-uniform and dense microstructures. The average grain size was around $1430 \mathrm{~nm}$ for Se of a $157 \mathrm{~nm}$ thickness, which is depicted in figure 8 (a). Similar structures have been reported by Gode et al. [49] for amorphous Zinc Sulphide thin films. For tin films of thickness $30 \mathrm{~nm}$ by using TEM, figure 8 (b) shows grains were small with non-uniform shape and well-defined grain boundaries exist. The largest grain has a size of $4.4 \mu \mathrm{m}$.

Figure 8. (a) SEM images of Se thin films of magnification 10,000 for thicknesses $157 \mathrm{~nm}$, (b) SEM images of Se thin films of magnification 10,000 for thicknesses $210 \mathrm{~nm}$

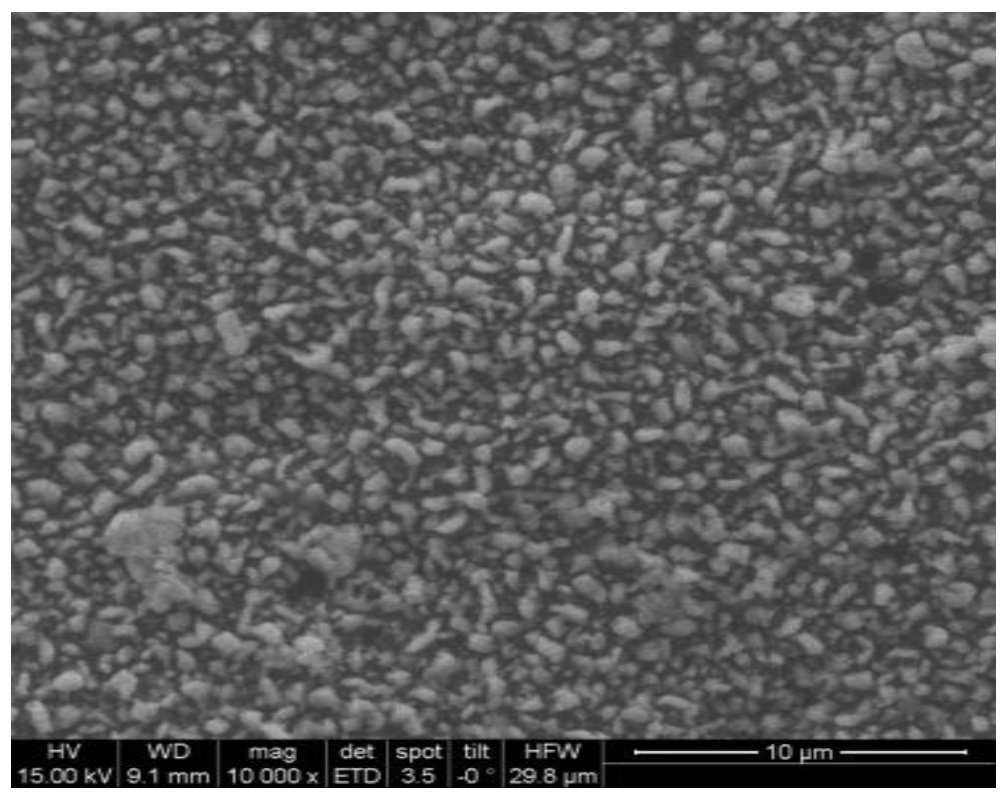

(a) 


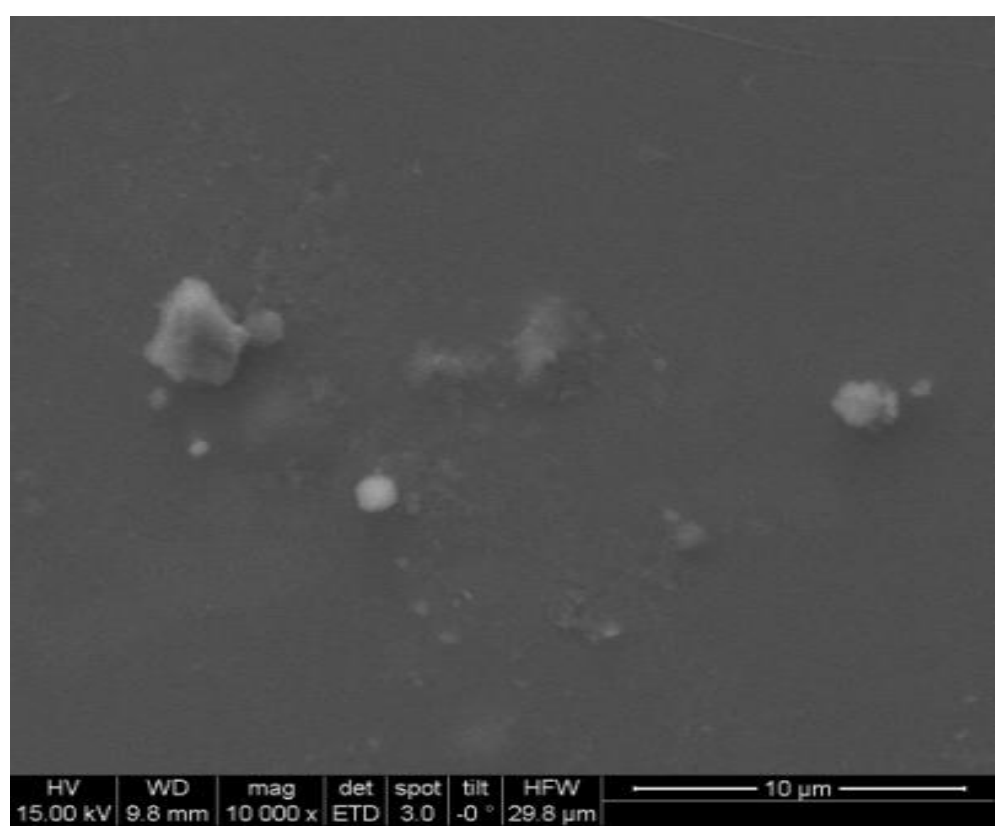

(b)

\section{Source: Own source.}

Atomic force microscopy (AFM) is a technique for analyzing the surface morphology and texture of a rigid material all the way down to the level of the atom. AFM utilizes a mechanical cantilever probe to magnify surface features up to 100,000,000 times and produces 3-D images of the surface of the sample.

If the film is continuous, homogeneous, and has no discontinuities, the AFM image is a reflection of that area. AFM measurements were performed to obtain the surface roughness of the Se films. Figure 9 (a-b) shows the AFM images with a scanning area of $5 \times 5 \mu \mathrm{m}^{2}$ of the films. It is clearly observed that the numerous protruded terraces and holes are randomly distributed on the surface of the films and these surfaces are not homogeneous and uniform. The roughness was estimated by root mean square (RMS value). The root mean square (RMS) roughness was about 182, $-115 \mathrm{~nm}$ and $64,-3.2 \mathrm{~nm}$, respectively, for Se films of thicknesses 157 and $210 \mathrm{~nm}$. It is noticed that the roughness of films decreases as the thickness increases as evidenced by the AFM images. Similar images were obtained for CdS and Ag films [50], [51]. It is known that the increase in the surface roughness may cause deterioration of the electrical and optical properties [52], [53] for $\mathrm{ZnO}$ and Tungsten doped $\mathrm{ZnO}$ thin films. 
Figure 9. (a) AFM images of Se thin films for thickness $157 \mathrm{~nm}$, (b) AFM images of Se thin films for thickness $210 \mathrm{~nm}$

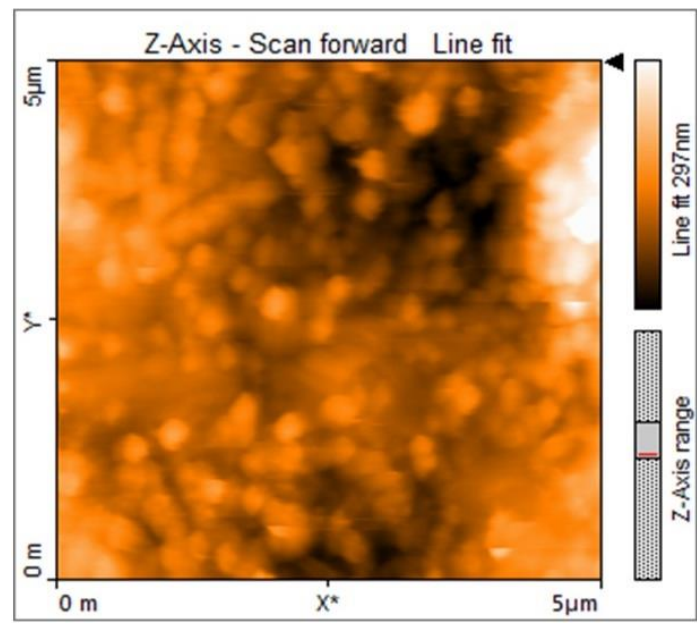

(a) (i)

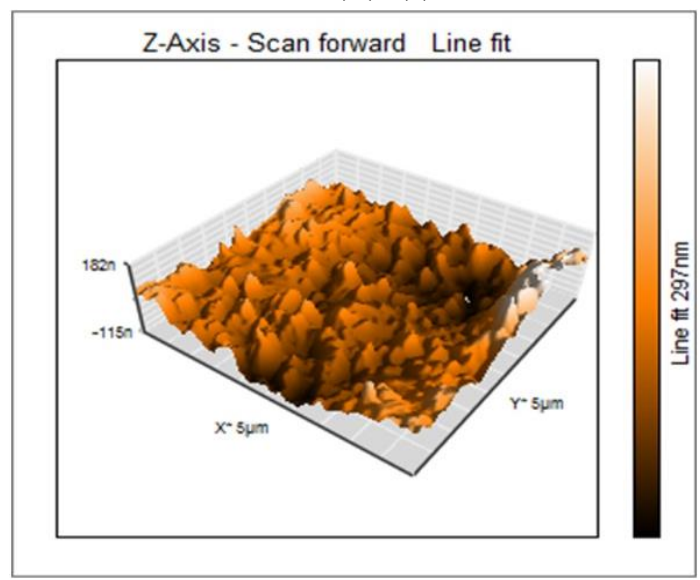

(a) (ii)

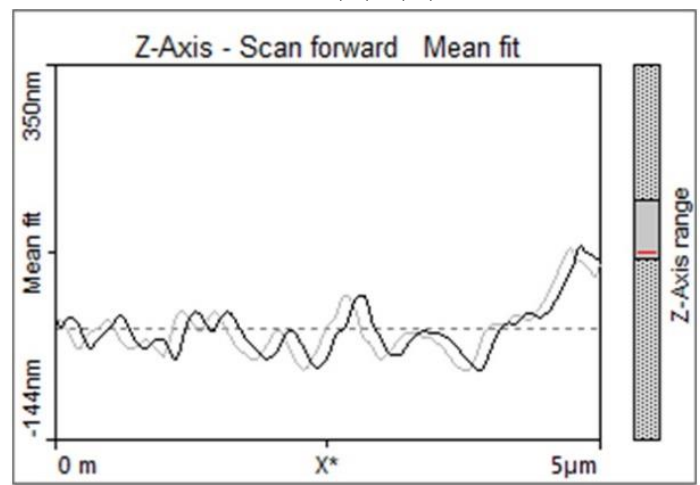

(a) (iii)

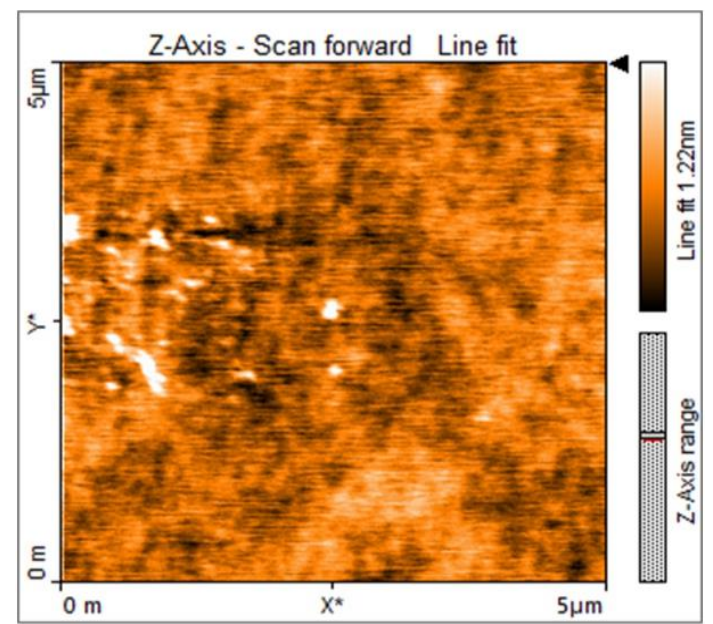

(b) (i)

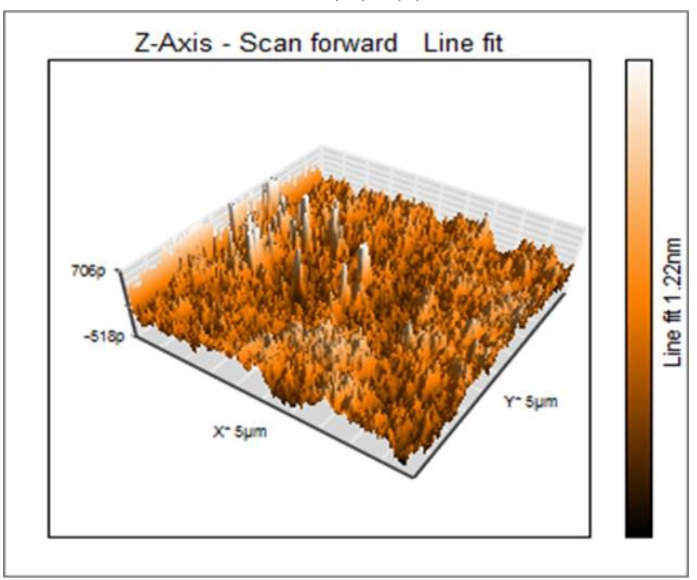

(b) (ii)

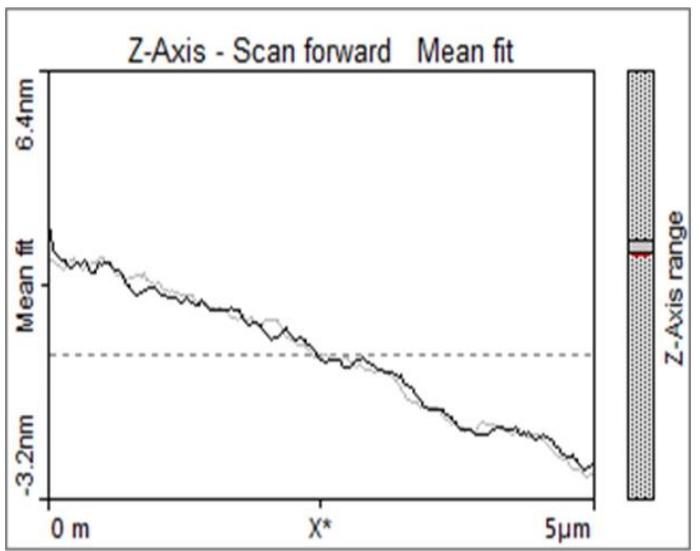

(b) (iii)

Source: Own source. 
Electron Dispersive Spectroscopy (EDS) analysis yields information on the quantitative analysis of the films, which was carried out using Scanning Electron Microscopy (SEM) measurements in order to study the stoichiometry of the films. Figure 10 shows the EDS pattern for Se film of thickness $210 \mathrm{~nm}$ with relative analysis and it confirms that the material used in the present investigation is Se. H Metin [54] has obtained a similar graph for the identification of CdS films and Senthil Kumaran et al. obtained an EDS pattern which exactly coincides with our results [55] for pure selenium films as indicated by the prominent peak in our spectra.

Figure 10. EDS spectra of Se films of thickness $210 \mathrm{~nm}$

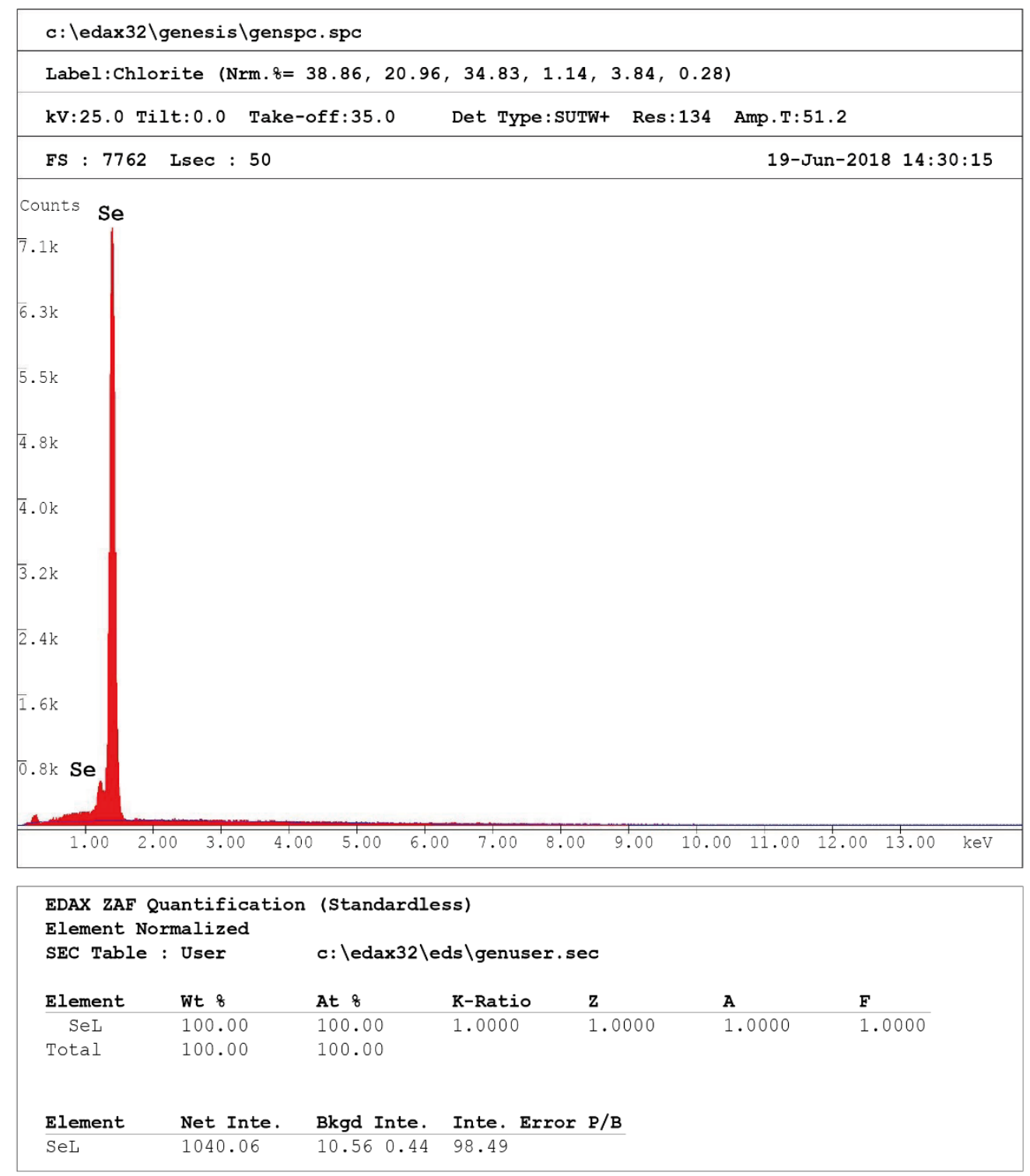

Source: Own source. 


\section{Conclusion}

The following conclusions may be drawn from the results obtained.

We have successfully grown the thin films of $\mathrm{Se}$ on glass substrates held at room temperature below the De Broglie wave-length limit by thermal evaporation in vacuum. The XRD analysis reveals that structure of Se is amorphous. The direct band gap energy calculated from absorption data are in the range (2.0-2.3) eV, which is in good agreement with the expected value. The results were found to be in consistent with other studies that used different procedures. The direct band gap decreases from $2.3 \mathrm{eV}$ to $2.0 \mathrm{eV}$ as the thickness increases. The optical band gap energy of thin Se films has been found to obey the inverse square law with respect to thickness. The optical density studied is found to be a function of film thickness. The effective electron mass estimated from this investigation $\left(0.3375 \times 10^{-4}\right)$ times $m_{o}$ is comparable to that obtained by other authors. The absorption coefficients were in the range $(0.5-4.0) \times 10^{7} \mathrm{~m}^{-1}$. The AFM results confirmed that the Se nanosize increases with the increase in the film thickness. Both the grain boundaries and sub-grain regions are clearly visible in the SEM micrographs. We observe that the grain and sub-grain microstructure is a result of the bombardment of growth surface by energetic ions during deposition. The EDS spectra confirms the material used in the present investigation is pure selenium.

\section{Acknowledgement}

The authors Prof. Dr. L. A. Udachan and Prof. Dr. N. H. Ayachit acknowledge the Vision Group on Science \& Technology, Government of Karnataka, India, for providing the necessary research facility for carrying out the research work and the instruments procured under grant sanctioned, bearing GRD No. 185 \& GRD No. 539, respectively.

\section{References}

[1] M. C. Zouaghi, T. Ben Nasrallah, S. Marsillac, J. C. Bernede, and S. Belgacem, "Physico-chemical characterization of spray-deposited CuInS ${ }_{2}$ thin films," Thin Solid Films, vol. 382, nos. 1-2, pp. 3946, 2001. Available: https://doi.org/10.1016/S0040-6090(00)01699-0

[2] A. A. Al Ghamdi, "Optical band gap and optical constants in amorphous $\mathrm{Se}_{96-\mathrm{x}} \mathrm{Te}_{4} \mathrm{Ag}_{\mathrm{x}}$ thin films," Vacuum, vol. 80, no. 5, pp. 400-405, 2006. Available: https://doi.org/10.1016/j.vacuum.2005.07.003

[3] C. Rajashree, A. R. Balu, and V. S. Nagarethinam, Substrate Temperature effect on the Physical properties of Spray deposited Lead sulfide Thin Films suitable for Solar control coatings," Int. J. ChemTech R., vol. 6, no. 1, pp. 347-360, 2014. Available: https://www.semanticscholar.org/paper/Substrate-Temperature-effect-on-the-Physical-of-forRajashree-Balu/06937ef83920219bcd60f1a8d1b02a030159bace 
[4] V. Sivaranjani and P. Philominathan, "Influence of substrate temperature on physical properties of nanostructured Ti Doped In2O3 thin films by a simplified perfume atomizer technique," Int. J. Thin Films Sci. Technol., vol. 4, no. 3, pp. 219-225, 2015. Available: http://www.naturalspublishing.com/Article.asp?ArtcID=9622

[5] D. C. Sati, R. Kumar, and R. M. Mehra, "Influence of thickness on optical properties of a: $\mathrm{As}_{2} \mathrm{Se}_{3}$ Thin Films," Turk. J. Phys., vol. 30, pp. 519- 527, 2006. Available: https://dergipark.org.tr/en/download/article-file/130769

[6] C.-C. Kuo, C.-C. Liu, S.-C. He, J.-T. Chang, and J.-L. He, "The influences of thickness on the optical and electrical properties of dual-ion-beam sputtering-deposited molybdenum-doped zinc oxide layer," J. Nanomater., 2011. Available: https://doi.org/10.1155/2011/140697

[7] R. M. Krishnan and F. O. Meyer III, "Quantum size effect," Thin Solid Films, vol. 23, no. 1, pp. 713, 1974. Available: https://doi.org/10.1016/0040-6090(74)90212-0

[8] M. A. Angadi and L. A. Udachan, "The effect of the deposition rate on the electrical resistivity of thin tin films," Thin Solid Films, vol. 78, no. 3, pp. 299-302, 1981. https://doi.org/10.1016/0040$\underline{6090(89) 90597-X}$

[9] M. A. Angadi and L. A. Udachan, "The effect of substrate temperature on the electrical properties of thin chromium films," J. Mater. Sci., vol. 16, pp. 1412-1415, 1981.

[10] M. R. A. Bhuiyan, D. K. Saha, and S. M. Firoz Hasan, "Structural and electrical properties of polycrystalline AgxGa2-xSe2 $(0.4 \leq \mathrm{x} \leq 1.6)$ thin films," Indian J. Pure Appl. Phys., vol. 47, pp. 787-792, 2009.

[11] S. Sankar and K. G. Gopchandran, "Effect of growth parameters on structural, electrical and optical properties of titanium oxide thin films," Indian J. Pure Appl. Phys., vol. 46, no. 11, pp. 791-796, Nov. 2008. Available: http://nopr.niscair.res.in/handle/123456789/2598

[12] L. U. Shiva, N. H. Ayachit, L. A. Udachan, A. V. Banagar, S. S. Kolkundi, and S. S. Bhairamadagi, "Influence of substrates on the electrical properties of thin tin films," Bulgarian J. Phys., vol. 45, no. 1, pp. 35-43, 2018.

[13] R. Sethi, S. Ahmad, A. Aziz, and A. Majid Siddiqui, "Structural, optical and electrical properties of tin oxide thin films for application as a wide band gap semiconductor," in AIP Conference Proceedings 1675, 2015. Available: http://doi.org/10.1063/1.4929255

[14] S. Al-Ani, M. N. Al-Delaimi, A. H. Al-Hamdani, and H. M. Jawher, "Optical and electrical properties of pure and doped amorphous thin selenium films," Int. J. Electron., vol. 69, no. 1, pp. 87-95, 1990. Available: https://doi.org/10.1080/00207219008920294

[15] R. Roy, V. S. Choudhary, M. K. Patra, and A. Pandya, "Effect of annealing temperature on the electrical and optical properties of nanocrystalline selenium thin films," J. Optoelectron. Adv. Mater., vol. 8, pp. 1352-1355, 2006.

[16] W. C. Tan, “Optical Properties of Amorphous Selenium Films”, M.S. thesis, Dep. Elect. Eng, Univ. Saskatchewan, Saskatchewan, Canada, $2006 . \quad$ Available: https://core.ac.uk/download/pdf/226119535.pdf

[17] R. Zhang et al., "Visible-light-respnsive t-se nanorods photocatalysts: Synthesis, properties, and mechanism," RSC Adv., vol. 5, no. 56, pp. 1-9, 2015. Available: https://doi.org/10.1039/C5RA03895B

[18] K. Tanaka, "Gap states in non-crystalline selenium: Roles of defective structures and impurities," $J$. Optoelectron. Adv. Mater., vol. 17, no. 11, pp. 1716-1727, 2017.

[19] D. S. Deng, N. D. Orf, S. Danto, A. F. Abouraddy, J. D. Joannopoulos, and Y. Fink, "Processing and properties of centimeter-long, in-fiber, crystalline-selenium filaments," Appl. Phyis. Lett., vol. 96, p. 023102, 2010. Available: https://doi.org/10.1063/1.3275751

[20] J. R. Scheuermann, A. H. Goldan, O. Tousignant, S. Léveillé, and W. Zhao, "Development of solidstate avalanche amorphous selenium for medical imaging," Med. Phys., vol. 42, no. 3, pp. 223-1226, 2015. doi:10.1118/1.4907971 
[21] T.-Y. Yu, F.-M. Pan, C.-Y. Chang, J.-S. Lin, and W.-H. Huang, "Thermal stability and photoconductive properties of photosensors with an alternating multilayer structure of amorphous $\mathrm{Se}$ and $\mathrm{As}_{\mathrm{x}} \mathrm{Se}_{1-\mathrm{x}}, "$ J. Appl. Phys., vol. 118, p. 044509, 2015. Available: https://doi.org/10.1063/1.4927740

[22] A. A. El-Amin, A. M. Badr, and F. Abdel-Wahaab, "Optical properties and determination of thermal transformation parameters for $\mathrm{Se}_{0.65} \mathrm{Te}_{0.35}$ high reflectance thin films," Turk. J. Phys., vol. 31, pp. 331-339, $2007 . \quad$ Available: https://www.researchgate.net/publication/253871024_Optical_Properties_and_Determination_of_Th ermal_Transformation_Parameters_for_Se065Te035_High_Reflectance_Thin_Films

[23] H. Singh, "Effects of additives on structural and optical properties of selenium thin films," Int. J. Comput. Sci. Eng., vol. 7, no. 2, pp. 549-552, 2019. Available: https://doi.org/10.26438/ijcse/v7i2.549552

[24] S. Sinha, S. K. Chatterjee, J. Ghosh, and A. K. Meikap, "Semiconducting selenium nanoparticles: Structural, electrical characterization, and formation of a back-to-back Schottky diode device," $J$. Appl. Phys., vol. 113, no. 12, p. 123704, 2013. Available: https://aip.scitation.org/doi/10.1063/1.4796106

[25] M. Singh, K. C. Bhahada, and Y. K. Vijay, "Variation of optical band gap in obliquely deposited selenium thin films," Indian J. Pure Appl. Phys., vol. 43, no. 2, pp. 129-131, 2005. Available: http://nopr.niscair.res.in/handle/123456789/8719

[26] R. S. Abed, H. S. Sabaa, and M. A. Muhsien, "Effect of deposition angle on optical properties of Selenium thin films," Int. J. Appl. Innovat. Eng. Man., vol. 2, no. 5, pp. 189-192, 2013. Available: https://www.ijaiem.org/Volume2Issue5/IJAIEM-2013-01-20-036.pdf

[27] S. A. J. Jassim, A. A. R. A. Zumaila, and G. A. A. A. Waly, "Influence of substrate temperature on the structural, optical and electrical properties of CdS thin films deposited by thermal evaporation," Results Phys., vol. 3, pp. 173-178, 2013. Available: http://dx.doi.org/10.1016/j.rinp.2013.08.003

[28] H. S. Shaaker, W. A. Hussain, and H. A. Badran, "Determination of the optical constants and optical limiting of doped malachite green thin films by the spray method," Adv. Appl. Sci. Res., vol. 3, no. 5, pp. 2940-2946, 2012. Available: https://www.imedpub.com/articles/determination-of-the-opticalconstants-and-optical-limiting-of-doped-malachitegreen-thin-films-by-the-spray-method.pdf

[29] P. H. Soni, J. R. Otia, and C. F. Desai, "Optical band gap of $\mathrm{Bi}_{2} \mathrm{Te}_{2.8} \mathrm{Se}_{0.2}$ thin films," Indian J. Eng. Mater. Sci., vol. 11, no. 3, pp. 221-223, 2004. Available: http://nopr.niscair.res.in/handle/123456789/9280

[30] N. Cicek Bezir, A. Evcin, R. Kayali, M. K. Ozen, and G. Balyaci, "Comparison of pure and doped TiO2 thin films prepared by Sol-Gel Spin-Coating Method," Acta Physica Polonica A, vol. 132, pp. 620-624, 2017. http://przyrbwn.icm.edu.pl/APP/PDF/132/app132z3p059.pdf

[31] B. Joseph, K. G. Gopchandran, P. K. Manoj, P. Koshy, and V. K. Vaidyan, "Optical and electrical properties of zinc oxide films prepared by spray pyrolysis," Bull. Mater. Sci., vol. 22, no. 5, pp. 921926, Aug. 1999. Available: https://doi.org/10.1007/BF02745554

[32] A. A. Abdul-Hamead, "Fabrication and AFM characterization of selenium recycled nano-particles by pulse laser evaporation and thermal evaporation," Mater. Res. Express, vol. 6, no. 12, Mar. 2020. Available: https://iopscience.iop.org/article/10.1088/2053-1591/ab6a50/meta

[33] N. M. Tashtoush and O. Alkasassbeh, "Determining optical constants of selenium thin films using the envelope method," Am. J. Appl. Sci., vol. 10, no. 2, pp. 164-171, 2013. Available: https://doi.org/10.3844/ajassp.2013.164.171

[34] F. Mutar and A. Hemed, "Effect of Thermal Annealing on the Structural, Optical, and Electrical Properties of a-Se Thin Films," Adv. Phys. Theories Appl., vol. 31, pp. 16-24, 2014. Available: https://www.iiste.org/Journals/index.php/APTA/article/view/12801 
[35] S. A. Jesuraj, S. Devadason, and M. M. D. Kumarc, "Effect of quantum confinement in CdSe/Se multilayer thin films prepared by PVD technique", Mater. Sci. Semiconduct. Proc., vol. 64, no. 15, pp. 109-114, 2017. Available: https://doi.org/10.1016/j.mssp.2017.03.019

[36] S. Baco, A. Chik, and F. Md. Yassin, "Study on optical properties of tin oxide thin film at different annealing temperature," J. Sci. Tech., vol. 4, no. 1, 2012. Available: https://publisher.uthm.edu.my/ojs/index.php/JST/article/view/468

[37] D.Singh, S. Kumar, R. Thangaraj, and T. S. Sathiaraj, "Influence of thickness on optical properties of a-( $\left.\mathrm{Se}_{80} \mathrm{Te}_{20}\right)_{96} \mathrm{Ag}_{4}$ thin films," Physica B: Condensed Matter, vol. 408, no. 1, pp. 119-125, 2013. Available: https://doi.org/10.1016/j.physb.2012.09.034

[38] S. Victor Vedanayakam and D. Punyaseshudu, "1/f noise studies on thin films of cadmium oxide", Mater. Phys. Mech., vol.18, pp. 1-10, 2013. Available: http://www.ipme.ru/ejournals/MPM/no_11813/MPM118_01_vedanayakam.html

[39] L. C. Nehru, M. Umadevi, and C. Sanjeeviraja, "Studies on Structural, Optical and Electrical Properties of ZnO Thin Films Prepared by the Spray Pyrolysis Method," Int. J. Mater. Eng., vol. 2, no. 1, pp. 12-17, 2012. Available: http://article.sapub.org/10.5923.j.ijme.20120201.03.html

[40] N. Kumar, U. Parihar, R. Kumar, K. J. Patel, C. J. Panchal, and N. Padha, "Effect of film thickness on optical properties of tin selenide thin films prepared by thermal evaporation for photovoltaic applications," Am. J. Mater. Sci., vol. 2, no. 1, pp. 41-45, 2012. Available: http://article.sapub.org/10.5923.j.materials.20120201.08.html

[41] S. M. Vyas, M. Patel, S. Thakor, and V. Patel, "Optical Properties of Thin Film of Bi2Te3-XSeX (X=0.1\&0.5) Compounds,” IJLTEMAS, vol. III, no. V, pp. 166-168, May 2014. Available: https://www.ijltemas.in/DigitalLibrary/Vol.3Issue5/166-168.pdf

[42] A. M. Karguppikar, and A. G. Vedeshwar, "Thickness dependence of the forbidden energy gap in stibnite $\left(\mathrm{Sb}_{2} \mathrm{~S}_{3}\right)$ thin films," Phys. Lett. A, vol. 126, no. 2, pp. 123-126, 1987. Available: https://doi.org/10.1016/0375-9601(87)90570-6

[43] M. H. Suhail, "Structural and optical properties of $\mathrm{ZnS}, \mathrm{PbS}, \mathrm{Zn}_{1-\mathrm{x}} \mathrm{Pb}_{\mathrm{x}} \mathrm{S}, \mathrm{Zn}_{\mathrm{x}} \mathrm{Pb}_{1-\mathrm{x}} \mathrm{S}$ and $\mathrm{PbZn}_{\mathrm{x}} \mathrm{S}_{1-\mathrm{x}}$ thin films," Indian J. Pure Appl. Phys., vol. 50, n. 06, pp. 380-386. 2012. Available: http://nopr.niscair.res.in/handle/123456789/14180

[44] A. Tumuluri, K. Lakshun Naidu, and K. C. James Raju, "Band gap determination using Tauc's plot for $\mathrm{LiNbO}_{3}$ thin films," Int. J.ChemTech Res., vol. 6, no. 6, pp. 3353-3356, 2014. Available: http://sphinxsai.com/2014/vol6_6_ICMCT/4/(3353-3356)ICMCT14.pdf.

[45] E. I. Rogacheva, S. I. Menshikova, A. Yu Sipatov, and O. N. Nashchekina, "Thickness-dependent quantum oscillations of the transport properties in bismuth selenide thin films," Thin Solid Films, vol. 684, pp. 31-35, 2019. Available: https://doi.org/10.1016/j.tsf.2019.05.046

[46] P. H, Soni, S. R. Bhavsar, G. R. Pandya, and C. F. Desai, "Optical band gap of In 0.1Bi 1.9Te 3 thin films," Indian J. Pure Appl. Phys., vol. 46, no. 11, pp. 806-808, 2008.

[47] A. S. Hassanien and A. A. Akl, "Influence of composition on optical and dispersion parameters of thermally evaporated non-crystalline $\mathrm{Cd}_{50} \mathrm{~S}_{50-x} \mathrm{Se}_{\mathrm{x}}$ thin films," J. Alloys Compd., vol. 648, pp. 280290, 2015. Available: https://doi.org/10.1016/j.jallcom.2015.06.231

[48] L. Shiva, N. Ayachit, L. Udachan, A. Banagar, S. Kolkundi, and S. Bhairamadagi, "A study on nucleation, growth and grain boundary reflection in thin tin nanofilms," J. Phys. Conf. Ser., vol. 1186, no. 1, pp. 012006, 2018. Available: https://doi.org/10.1088/1742-6596/1186/1/012006

[49] F. Gode, S. Guneri, A. Kariper, C. Ulutas, F. Kirmizigul and C. Gumus, "Influence of annealing temperature on the structural, optical and electrical properties of amorphous Zinc Sulphide thin films," J. Phys. Conf. Ser., vol. 326, p. 012020, 2011. Available: https://doi.org/10.1088/1742$\underline{6596 / 326 / 1 / 012020}$

[50] S. Elmas, S. Ozcan, S. Ozder, and V. Bilgin, "Influence of annealing temperature on the electrical and optical properties of CdS thin films," Acta Physica Polonica A, vol. 121, no. 1, pp. 56-58, 2012. Available: https://pdfs.semanticscholar.org/ba52/81dc06023b8b0e5e29f4af58f43de12da5bc.pdf 
[51] A. C. Scheid et al., "Silver nanoparticle thin films deposited on glass surface using an ionic silsesquioxane as stabilizer and as crosslinking agent," J. Braz. Chem. Soc., vol. 26, no. 5, pp. 1004 1012, 2015. Available: https://doi.org/10.5935/0103-5053.20150066.

[52] A. Taabouche et al., "Effect of substrates on the properties of $\mathrm{ZnO}$ thin films grown by pulsed laser deposition," Adv, Mater. Phys. Chem., vol. 3, no. 4, pp. 209-213, 2013. Available: https://www.scirp.org/journal/PaperInforCitation.aspx?PaperID=36086

[53] B. D. Ngom et al., "Structural and optical properties of nano-structured tungsten-doped $\mathrm{ZnO}$ thin films grown by pulsed laser deposition," Appl. Surface Sci., vol. 255, no. 7, pp. 4153-4158, 2009. Available: https://doi.org/10.1016/j.apsusc.2008.10.122

[54] H. Metin, F. Sat, S. Erat, and M. Ari. "Cadmium Sulphide Thin films grown by CBD: The effect of thermal annealing on the structural, electrical and optical properties," J. Optoelectron. Adv. Mater., vol. 10, no. $10, \quad$ pp. 2622-2630, 2008. Available: https://www.researchgate.net/publication/286302595_Cadmium_sulphide_thin_films_grown_by_CB D_The_effect_of_thermal_annealing_on_the_structural_electrical_and_optical_properties

[55] C. K. Senthil Kumaran et al., "Synthesis and Characterization of Selenium Nanowires," Int. Schol. Res. Net. Nanotechn., pp.1-4, 2011. Available: https://doi.org/10.5402/2011/589073 


\section{Appendices}

Table 2. Plot of transmittance (T \%) versus wave-length $(\lambda)$ of incident photon at different Se films thicknesses (t)

\begin{tabular}{|c|c|c|c|c|c|c|c|c|}
\hline $\begin{array}{c}\text { Sl. } \\
\text { No. }\end{array}$ & $\begin{array}{l}\text { Wave- } \\
\text { length in } \\
\text { nm }\end{array}$ & $\begin{array}{c}\text { Thickness } \\
\left(\mathbf{t}_{1}\right)= \\
200 \mathrm{~nm}\end{array}$ & $\begin{array}{c}\text { Thickness } \\
\left(\mathbf{t}_{2}\right)= \\
350 \mathrm{~nm}\end{array}$ & $\begin{array}{c}\text { Thickness } \\
\left(\mathbf{t}_{3}\right)= \\
500 \mathrm{~nm}\end{array}$ & $\begin{array}{c}\text { Thickness } \\
\left(\mathbf{t}_{4}\right)=600 \\
\mathrm{~nm}\end{array}$ & $\begin{array}{c}\text { Thickness } \\
\left(\mathbf{t}_{5}\right)=700 \\
\text { nm }\end{array}$ & $\begin{array}{c}\text { Thickness } \\
\begin{array}{c}\left(\mathbf{t}_{6}\right)=850 \\
\text { nm }\end{array}\end{array}$ & $\begin{array}{c}\text { Thickness } \\
\left(t_{7}\right)=1000 \\
\text { nm }\end{array}$ \\
\hline & $(\lambda)$ & $\mathbf{T}_{1} \%$ & $\mathrm{~T}_{2} \%$ & $\mathbf{T}_{3} \%$ & $\mathbf{T}_{4} \%$ & $\mathbf{T}_{5} \%$ & $\mathbf{T}_{6} \%$ & $\mathbf{T}_{7} \%$ \\
\hline 1 & 250 & 60 & 59.5 & 48.5 & 52 & 55 & 51 & 48.5 \\
\hline 2 & 300 & 52.5 & 49 & 45 & 56 & 48.5 & 55.5 & 39 \\
\hline 3 & 350 & 59 & 53 & 51 & 51 & 55.5 & 52.5 & 44.5 \\
\hline 4 & 400 & 57.5 & 53.5 & 48 & 50 & 53.5 & 53 & 43 \\
\hline 5 & 450 & 59 & 58 & 53.5 & 55 & 58 & 60 & 48 \\
\hline 6 & 500 & 65 & 62.5 & 59.5 & 60 & 61.2 & 65 & 55.5 \\
\hline 7 & 550 & 75 & 68 & 65.5 & 63 & 67.5 & 70.5 & 61 \\
\hline 8 & 600 & 55 & 64 & 65 & 53.5 & 67 & 71 & 65 \\
\hline 9 & 650 & 55.5 & 66 & 56.5 & 51.5 & 61.5 & 53.5 & 62.5 \\
\hline 10 & 700 & 65 & 65 & 65 & 55 & 65 & 45 & 65 \\
\hline 11 & 750 & 68.5 & 65.5 & 62.5 & 61 & 62 & 48 & 64 \\
\hline 12 & 800 & 69.5 & 64 & 63 & 55 & 62.5 & 60 & 65.5 \\
\hline
\end{tabular}

Source: Own source. 
Table 3. Plot of absorption co-efficient $(\alpha)$ versus photon energy, hv in eV at different Se films thicknesses ( $t$ )

\begin{tabular}{|c|c|c|c|c|c|c|c|c|}
\hline $\begin{array}{l}\text { Sl. } \\
\text { No. }\end{array}$ & $\begin{array}{c}\text { Photon } \\
\text { energy } \\
\text { in eV }\end{array}$ & $\begin{array}{c}\text { Thickness } \\
\left(\mathbf{t}_{1}\right)= \\
200 \mathrm{~nm}\end{array}$ & $\begin{array}{c}\text { Thickness } \\
\left(\mathbf{t}_{2}\right)= \\
350 \mathrm{~nm}\end{array}$ & $\begin{array}{c}\text { Thickness } \\
\left(\mathbf{t}_{3}\right)= \\
500 \mathrm{~nm}\end{array}$ & $\begin{array}{c}\text { Thickness } \\
\left(t_{4}\right)=600 \\
n m\end{array}$ & $\begin{array}{c}\text { Thickness } \\
\left(t_{5}\right)=700 \\
n m\end{array}$ & $\begin{array}{c}\text { Thickness } \\
\left(t_{6}\right)=850 \\
n m\end{array}$ & $\begin{array}{c}\text { Thickness } \\
\left(t_{7}\right)=1000 \\
n m\end{array}$ \\
\hline & hv & $\alpha_{1} \times 10^{7} / m$ & $\begin{array}{c}\alpha_{2} \times \\
10^{7} / \mathrm{m} \\
\end{array}$ & $\begin{array}{c}\alpha_{3} \times \\
10^{7} / \mathrm{m} \\
\end{array}$ & $\alpha_{4} \times 10^{7} / \mathrm{m}$ & $\alpha_{5} \times 10^{7} / \mathrm{m}$ & $\alpha_{6} \times 10^{7} / \mathrm{m}$ & $\begin{array}{c}\alpha_{7} \mathrm{X} \\
10^{7} / \mathrm{m} \\
\end{array}$ \\
\hline 1 & 4.96 & 3.34 & 1.91 & 1.44 & 1.051 & 0.853 & 0.767 & 0.806 \\
\hline 2 & 4.14 & 3.22 & 2.03 & 1.59 & 1.038 & 0.8 & 0.782 & 0.84 \\
\hline 3 & 3.54 & 3.05 & 1.81 & 1.34 & 1.048 & 0.847 & 0.773 & 0.852 \\
\hline 4 & 3.1 & 2.92 & 1.78 & 1.46 & 1.03 & 0.853 & 0.684 & 0.853 \\
\hline 5 & 2.76 & 2.63 & 1.55 & 1.25 & 0.958 & 0.777 & 0.627 & 0.76 \\
\hline 6 & 2.48 & 2.15 & 1.34 & 1.03 & 0.85 & 0.7 & 0.493 & 0.698 \\
\hline 7 & 2.25 & 1.42 & 1.1 & 0.71 & 0.769 & 0.56 & 0.444 & 0.644 \\
\hline 8 & 2.07 & 1.55 & 1.27 & 0.86 & 0.835 & 0.571 & 0.483 & 0.591 \\
\hline 9 & 1.91 & 1.67 & 1.18 & 0.9 & 0.905 & 0.568 & 0.523 & 0.64 \\
\hline 10 & 1.77 & 1.8 & 1.23 & 0.86 & 0.977 & 0.613 & 0.564 & 0.691 \\
\hline 11 & 1.65 & 1.88 & 1.2 & 0.94 & 1.048 & 0.682 & 0.606 & 0.741 \\
\hline 12 & 1.55 & 1.82 & 1.27 & 0.92 & 0.995 & 0.67 & 0.645 & 0.789 \\
\hline
\end{tabular}

Source: Own source. 
Table 4. Plot of ( $\alpha \mathrm{hv}) 2$ versus photon energy, hv in $\mathrm{eV}$ at different Se films thicknesses

$(t)$

\begin{tabular}{|c|c|c|c|c|c|c|c|c|}
\hline \multirow[b]{2}{*}{$\begin{array}{l}\text { Sl. } \\
\text { No. }\end{array}$} & \multirow[b]{2}{*}{$h v(e V)$} & \multicolumn{7}{|c|}{$(\alpha h v)^{2}$} \\
\hline & & $\begin{array}{c}t_{1}= \\
200 \mathrm{~nm}\end{array}$ & $\begin{array}{c}t_{2}= \\
350 \mathrm{~nm}\end{array}$ & $\begin{array}{c}t_{3}= \\
500 \mathrm{~nm}\end{array}$ & $\begin{array}{c}t_{4}= \\
600 \mathrm{~nm}\end{array}$ & $\begin{array}{c}t_{5}= \\
700 \mathrm{~nm}\end{array}$ & $\begin{array}{c}t_{6}= \\
850 \mathrm{~nm}\end{array}$ & $\begin{array}{c}t_{7}= \\
1000 \mathrm{~nm}\end{array}$ \\
\hline 1 & 4.96 & 275 & 90 & 51.48 & 27.22 & 17.94 & 14.5 & 16 \\
\hline 2 & 4.14 & 177.74 & 71.14 & 43.71 & 18.5 & 12.5 & 10.5 & 12.1 \\
\hline 3 & 3.54 & 117 & 41.19 & 22.7 & 13.78 & 9 & 7.5 & 9.1 \\
\hline 4 & 3.1 & 82 & 30.68 & 20.68 & 10.2 & 7 & 4.5 & 7 \\
\hline 5 & 2.76 & 53.03 & 18.45 & 11.92 & 7 & 4.61 & 3 & 4.4 \\
\hline 6 & 2.48 & 28.53 & 11.09 & 6.63 & 4.45 & 3.02 & 1.5 & 3 \\
\hline 7 & 2.25 & 10.29 & 6.13 & 2.58 & 3 & 1.59 & 1 & 2.1 \\
\hline 8 & 2.07 & 10.3 & 6.95 & 3.18 & 3 & 1.4 & 1 & 1.5 \\
\hline 9 & 1.91 & 10.3 & 5.14 & 4.75 & 3 & 1.18 & 1 & 1.5 \\
\hline 10 & 1.77 & 10.3 & 4.74 & 2.32 & 3 & 1.18 & 1 & 1.5 \\
\hline 11 & 1.65 & 9.71 & 3.97 & 2.4 & 3 & 1.27 & 1 & 1.5 \\
\hline 12 & 1.55 & 8 & 3.9 & 2.03 & 2.38 & 1.08 & 1 & 1.5 \\
\hline
\end{tabular}

Source: Own source.

Table 5. Plot of band gap energy Eg in eV versus (1|t2) for Se thin films of various thicknesses (t)

\begin{tabular}{ccc}
\hline $\begin{array}{c}\text { Sl. } \\
\text { No. }\end{array}$ & Eg in eV & $\left(\mathbf{1} \mid \mathbf{t}^{\mathbf{2}}\right) \mathbf{\times} \mathbf{1 0}^{\mathbf{1 2}} \mathbf{~ m}^{-\mathbf{2}}$ \\
\hline 1 & 2.30 & 25.0 \\
\hline 2 & 2.24 & 8.16 \\
\hline 3 & 2.18 & 4.00 \\
\hline 4 & 2.12 & 2.77 \\
\hline 5 & 2.06 & 2.04 \\
\hline 6 & 2.00 & 1.38 \\
\hline 7 & 2.00 & 1.00 \\
\hline
\end{tabular}

Source: Own source.

INGENIERÍA Y UNIVERSIDAD: ENGINEERING FOR DEVELOPMENT | COLOMBIA | V. 25 | 2021 | ISSN: 0123-2126 /2011-2769 (0nline) | Pág. 23 
Table 6. Plot of optical density [(OD) $(\alpha \times t) \times 10-14]$ versus the photon energy at Se various films thicknesses ( $t$ )

\begin{tabular}{|c|c|c|c|c|c|c|c|c|}
\hline & & $\mathbf{t}_{1}$ & $\mathbf{t}_{2}$ & $\mathbf{t}_{3}$ & $\mathbf{t}_{4}$ & $\mathbf{t}_{5}$ & $\mathbf{t}_{6}$ & $\mathbf{t}_{7}$ \\
\hline & & $200 \mathrm{~nm}$ & $350 \mathrm{~nm}$ & $500 \mathrm{~nm}$ & $600 \mathrm{~nm}$ & $700 \mathrm{~nm}$ & $850 \mathrm{~nm}$ & $1000 \mathrm{~nm}$ \\
\hline $\begin{array}{r}\text { Sl. } \\
\text { No. }\end{array}$ & hv $(\mathrm{eV})$ & $\alpha_{1} t_{1} \times 10^{14}$ & $\alpha_{2} t_{2} \times 10^{14}$ & $\alpha_{3} t_{3} \times 10^{14}$ & $\alpha_{4} t_{4} \times 10^{14}$ & $\alpha_{5} t_{5} \times 10^{14}$ & $\alpha_{6} t_{6} \times 10^{14}$ & $\alpha_{7} t 7 \times 10^{14}$ \\
\hline 1 & 4.96 & 6.68 & 6.69 & 7 & 6.31 & 5.97 & 6.52 & 8.06 \\
\hline 2 & 4.14 & 6.44 & 7.11 & 7.95 & 6.23 & 5.6 & 6.65 & 8.4 \\
\hline 3 & 3.54 & 6.1 & 6.34 & 6.7 & 6.23 & 5.93 & 6.57 & 8.52 \\
\hline 4 & 3.1 & 5.84 & 6.23 & 7.3 & 6.18 & 5.91 & 5.81 & 8.53 \\
\hline 5 & 2.76 & 5.23 & 5.43 & 6.23 & 5.75 & 5.44 & 5.33 & 7.6 \\
\hline 6 & 2.48 & 4.3 & 5.53 & 5.15 & 5.1 & 4.9 & 4.19 & 6.98 \\
\hline 7 & 2.25 & 2.84 & 3.85 & 3.55 & 4.61 & 3.92 & 3.77 & 6.44 \\
\hline 8 & 2.07 & 3.1 & 4.45 & 4.3 & 5.01 & 4 & 4.11 & 5.91 \\
\hline 9 & 1.91 & 3.34 & 4.13 & 4.5 & 5.43 & 3.98 & 4.44 & 6.4 \\
\hline 10 & 1.77 & 3.6 & 4.31 & 4.3 & 5.86 & 4.29 & 4.79 & 6.91 \\
\hline 11 & 1.65 & 3.76 & 3.62 & 4.7 & 6.23 & 4.77 & 5.15 & 7.41 \\
\hline 12 & 1.55 & 3.64 & 4.45 & 4.6 & 5.97 & 4.69 & 5.48 & 7.89 \\
\hline
\end{tabular}

Source: Own source.

Table 7. Plot of Energy gap (Eg) versus thickness ( $t$ ) for Se thin films of various thicknesses

\begin{tabular}{ccc}
\hline $\begin{array}{c}\text { Sl. } \\
\text { No. }\end{array}$ & Thickness $(\mathbf{t})$ in $\mathbf{~ m}$ & Band gap. $\mathbf{E}_{\mathbf{g}}$ in $\mathbf{~} \mathbf{V}$ \\
\hline 1 & 200 & 2.30 \\
\hline 2 & 350 & 2.24 \\
\hline 3 & 500 & 2.18 \\
\hline 4 & 600 & 2.12 \\
\hline 5 & 700 & 2.06 \\
\hline 6 & 850 & 2.00 \\
\hline 7 & 1000 & 2.00 \\
\hline
\end{tabular}

Source: Own source.

INGENIERÍA Y UNIVERSIDAD: ENGINEERING FOR DEVELOPMENT | COLOMBIA | V. 25 | 2021 | ISSN: 0123-2126 /2011-2769 (Online) | Pág. 24 